\title{
Morphological Evaluation of Endometrium in Women with Recurrent Miscarriage
}

\author{
Alina V Solovyova ${ }^{1 *}$, Viola Gace ${ }^{1}$ and Olga P Gerasimova ${ }^{2}$ \\ ${ }^{1}$ Department of obstetrics and gynecology, Peoples' Friendship University of Russia, Russia \\ ${ }^{2}$ Candidate of Medical Sciences, Head of Medical Center "Arbatlinik", Russia
}

Submission: December 04, 2017; Published: December 14, 2017

*Corresponding author: Alina V Solovyova, Doctor of medicine, professor of the Department of obstetrics and gynecology with the course of perinatology of the Peoples Friendship University of Russia (RUDN University), Moscow, Russian Federation, Tel: +79854477928; Email:av_soloveva@mail.ru

\section{Annotation}

Recurrent miscarriage is one of the first problems of obstetrics [1,2]. The habitual loss of pregnancy has many factors: anatomical, autoimmune, genetic, inflammatory, etc [3]. A qualified pathomorphological study of aspirates from the uterine cavity may help to identify the cause of pregnancy "fading" and solve diagnostic problems and therapeutic measures [4].

Keywords: recurrent miscarriage, inflammation of the endometrium, viral-bacterial associations.

\section{Objective}

To evaluate the histological structure of the endometrial aspirate in women with habitual miscarriage.

\section{Mini Review}

We examined 78 women who applied to the clinic to get rid from an undeveloped pregnancy and had a history of pregnancy with abortive outcome.

The pathomorphological study of aspirates was performed at the Research Institute of Human Morphology, Russian Academy of Medical Sciences, under the guidance of Corresponding Member of the Russian Academy of Natural Sciences, Professor Milovanov A.P.

In the endometrial material of 35 (44.9\%) women predominated signs of weak or insufficient decidualization of the stroma of parietal endometrium and utero-placental region. This is a sign of hormonal disturbances and the dominant cause was distinguished the "Lutein phase deficiency". In 15 (19.2\%) there were signs of massive thrombosis of microvessels in the parietal endometrium and retrochorial hematoma in the material under investigation, i.e. the dominant cause is "thrombohemorrhagic disorders".

The dominant cause was "Inflammation" if the studied material was dominated by the characteristic signs of acute abscess or chronic endometritis. This group included 28 (35.9\%) women. An acute abscessing variant was detected in 12 (42.9\%) women and was caused by viral agents. Morphologically, this variant was characterized by clusters of segmented leukocytes and local small lymphocytes that were detected throughout the entire endometrium: from flattened uterine epithelium to spongiosis, a zone dominated by endometrial glands. In their thickness, infected thrombi with the disappearance of the vascular wall due to its necrosis were often seen. In the individual epithelial cells of the glands were determined characteristic changes, which allowed to presume predominantly the viral etiology of acute abscessed endometritis. The presence of large epitheliocytes bulging into the lumen of the gland, with a characteristic large nucleus and a thin rim of the cytoplasm, indicated a possible lesion of the CMV glands (Figure 1). Large desquamated cells with large basophilic nuclei often occur in HSV II type lesion (Figure 2).

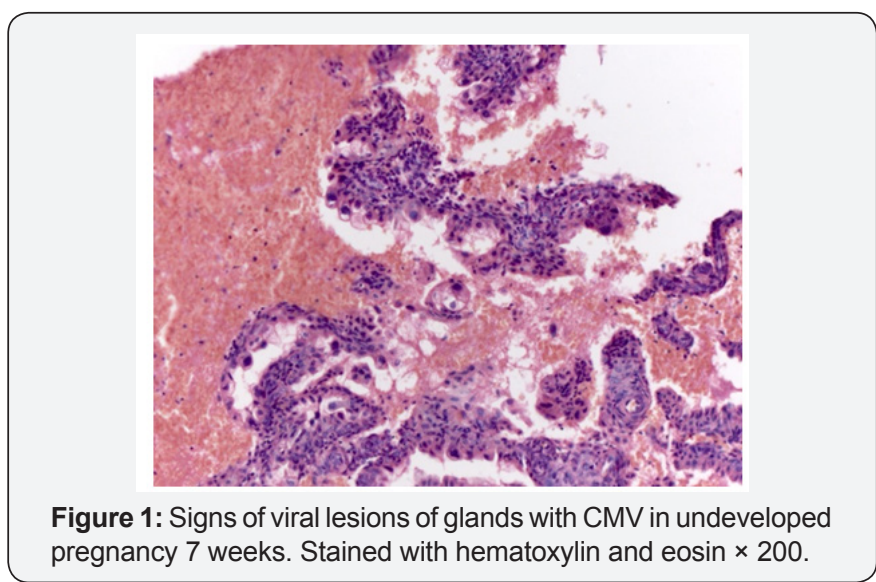




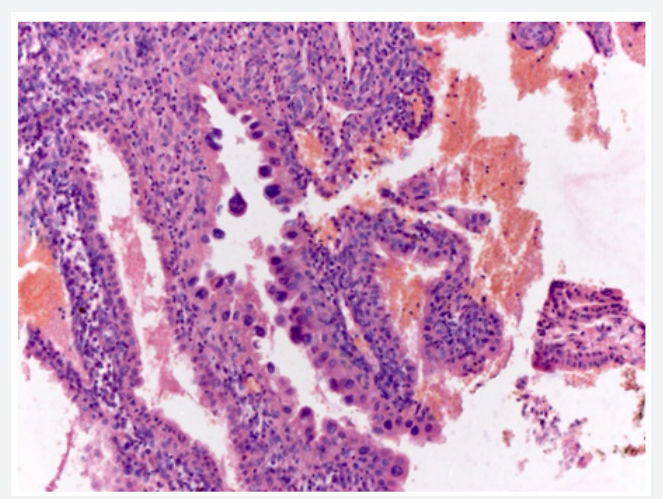

Figure 2: Signs of viral lesions of glands with HSV type 2. Stained with hematoxylin and eosin, $\times 200$.

Chronic endometritis was diagnosed in 16 (57.1\%) of 28 women in the "inflammation" subgroup. His morphological picture was different than in the acute abscessed form of inflammation and the picture was predominantly of bacterial origin. A characteristic pathomorphological feature of chronic endometritis was the concentration of lymphocytes around individual endometrial glands with their penetration through the wall into the lumens and this process was accompanied by partial or complete destruction of the gland epitheliocytes and the absence of secretion.
In the vaginal content of this cohort of women was often identified mixed bacterial and viral infections: HSV type II - in 24 (85.7\%), CMV - in 18 (64.3\%), Epstein-Barra - in 22 (78.6\%). Among the bacterial flora the leading were M. genitalium in 10 (35.7\%), U.urealyticum in $22(78.5 \%)$ and fungi of the genus C.albicans in 16 (57.1\%). Chlamydia infection and trichomoniasis were detected only in $1(3.6 \%)$ and $2(7.1 \%)$ women respectively.

Attention is drawn to the widespread prevalence of viral infection in the vaginal biotope in women with signs of inflammation in the endometrium. It is not known whether they play a causal role in the recurrent miscarriage or are a "concomitant" infection. This requires further research.

\section{References}

1. Donckers J, Scholten RR, Oyen WJ, Hopman MT, Lotgering FK, et al. (2012) Unexplained first trimester recurrent pregnancy loss and low venous reserves. Hum Reprod 27(9): 2613-2618.

2. Carp HJA (2014) Recurrent Pregnancy Loss: Causes, Controversies and treatment. In: Carp HJA (ed.), Series in Maternal-Fetal Medicine. $\left(2^{\text {nd }}\right.$ Edn), CRC Press, Boca Raton, Florida, United States, p. 456.

3. Radzinskiy VE (2016) Undevelopied pregnancy. In: Radzinskiy VE (ed.), ( $2^{\text {nd }}$ Edn), revised and additional, M: GEOTAR-Media, p. 176.

4. Milovanov AP (2011) Causes and differential treatment of early miscarriage: a guide for doctors. In: Milovanova AP, Serova OF (eds.), Production and Publishing Complex VINITI, Russia, p. 214.

Your next submission with Juniper Publishers
will reach you the below assets
- Quality Editorial service
- Swift Peer Review
- Reprints availability
- E-prints Service
- Manuscript Podcast for convenient understanding
- Global attainment for your research
- Manuscript accessibility in different formats
( Pdf, E-pub, Full Text, Audio)
- Unceasing customer service
Track the below URL for one-step submission
https://juniperpublishers.com/online-submission.php

